\section{Severe Sepsis Caused by California Serogroup Orthobunyavirus}

\section{Daniel K. Rogstad, Elizabeth Schiffman, David Neitzel, Larry M. Baddour}

Author affiliations: Loma Linda University, Loma Linda, California, USA (D.K. Rogstad); Mayo Clinic, Rochester, Minnesota, USA (D.K. Rogstad, L.M. Baddour); Minnesota Department of Health, St. Paul, Minnesota, USA (E. Schiffman, D. Neitzel)

\section{DOI: http://dx.doi.org/10.3201/eid2110.150394}

To the Editor: The California serogroup (CAL) of orthobunyaviruses, including Jamestown Canyon virus (JCV) and La Crosse virus (LACV), can cause neuroinvasive disease in humans $(1-3)$. The epidemiology and clinical spectrum of LACV are well described (3), whereas less is known about JCV.

JCV is distributed throughout temperate North Ameri$\mathrm{ca}$, and its transmission cycle involves ungulates and several mosquito genera (4-6). The first human case of JCV disease in Minnesota, USA, was reported in 2013 (7), although serologic evidence of the virus had been previously documented in the white-tailed deer population (8). Of the 22 human cases reported to the Centers for Disease Control and Prevention in the United States during 2013, 15 were neuroinvasive (7). However, given the lack of widespread testing availability and the few reported cases, the actual clinical spectrum of JCV infection, unlike that of LACV, remains unclear. We report a case of severe sepsis in an adult with antibodies against CAL and suspected JCV disease.

A 62-year-old man from Waseca County, Minnesota, who had type 2 diabetes mellitus, obesity, migraine headaches, depression, and anxiety, had been vacationing for 1 week at his cabin in Carlton County, Minnesota. On July 9, 2014, he experienced diffuse myalgia, arthralgia, and headache. He sought treatment July 10 at a local urgent care facility for fever, rigors, sweats, weakness, dizziness, poor appetite, and mild shortness of breath, but he denied having cough, chest pain, gastrointestinal symptoms, neck stiffness, and photophobia. He described extensive mosquito exposure the prior week. On physical examination, temperature was $38.8^{\circ} \mathrm{C}$, and he had multiple skin lesions consistent with mosquito bites. A 5-cm, lacy, petechial skin rash was observed on the right inner thigh. Chronic venous stasis changes of the lower extremities were noted, and a faint systolic cardiac murmur was heard. Peripheral leukocyte count was $11.2 \times 10^{9} \mathrm{cells} / \mathrm{L}$, and electrolyte levels were within reference ranges. Serologic screenings for likely infectious agents were negative (Table). Empiric doxycycline was initiated.
Two days later, he experienced worsening myalgia, arthralgia, fevers, profuse sweating, nausea, and vomiting and visited a local emergency department. Mild confusion was noted on examination. Temperature was $37.9^{\circ} \mathrm{C}$, and blood pressure was $69 / 32 \mathrm{~mm} \mathrm{Hg}$, with minimal improvement despite intravenous fluid administration. Peripheral leukocyte count was $16.2 \times 10^{9}$ cells $/ \mathrm{L}$, serum creatinine and bloodurea nitrogen levels were elevated at 1.7 and $37 \mathrm{mg} / \mathrm{dL}$, respectively, and liver enzyme and lactate levels were normal. Results of a chest radiograph were unremarkable. Dopamine and broad-spectrum antibiotic drugs were initiated, and he was transferred to Mayo Clinic (Rochester, Minnesota) in the intensive care unit. At that time, no confusion was noted, nor signs or symptoms of neuroinvasion that would have warranted cerebrospinal fluid examination or neuroimaging.

Hypotension resolved overnight, and leukocytosis and serum creatinine levels improved. A low-grade fever of $38.0^{\circ} \mathrm{C}$ was documented in the evening of July 14 . Because the overall etiology of the illness remained unclear, a computed tomography scan of the abdomen and pelvis was performed to investigate potential intraabdominal sources of sepsis, but results were unrevealing. By hospital day 5, blood cultures remained negative, leukocytosis resolved, and creatinine levels normalized. Antibiotic drugs were discontinued, and the patient was discharged with a 2-week course of oral doxycycline. Soon after discharge, an acutephase serum specimen was positive for a CAL orthobunyavirus (Table).

During the next 3 weeks, the man sought treatment multiple times as an outpatient for diarrhea, lightheadedness, dizziness, headache, fatigue, difficulties concentrating, and subjective memory loss. These symptoms gradually resolved over 2 months. Convalescent-phase serum samples were drawn 3 weeks after dismissal and showed 32-fold increased antibody titers against CAL. The Minnesota Department of Health was notified, and plaque reduction neutralization testing was ordered to determine the specific virus. Increases in the neutralizing antibody titers against JCV and LACV were noted; although the absolute titer was greater for JCV (Table), a final determination of which virus caused the patient's illness could not be made. Neutralizing antibodies in the acute-phase specimen in the absence of IgM suggests that the patient was previously exposed to an orthobunyavirus.

Antibody cross-reactivity between closely related arboviruses such as LACV and JCV is not unusual, and similar antigenic sin has been described with other orthobunyaviruses (9). Epidemiologic factors, including time of year, location of mosquito exposure, and the predilection of LACV disease for children, point to JCV infection in this case, although it cannot be confirmed.

Previous reports of JCV disease have focused on the ability of this virus to cause asymptomatic infection, 
Table. Pathogen testing in patient with undifferentiated severe sepsis, Minnesota, USA, 2014*

\begin{tabular}{|c|c|c|}
\hline \multirow[b]{2}{*}{ Pathogen tested } & \multicolumn{2}{|c|}{ Serum sample } \\
\hline & Acute phase & Convalescent phase \\
\hline $\mathrm{HIV}-1 /-2$ & $\mathrm{Ag} / \mathrm{Ab}$ screen negative & \\
\hline Leptospira & IgM/lgG negative & \\
\hline Cryptococcus & Antigen screen negative & \\
\hline Anaplasma phagocytophilum & IgG $<1: 64$, PCR negative & \\
\hline Ehrlichia chaffeensis & IgG $<1: 64$, PCR negative & \\
\hline Ehrlichia ewingii/canis & PCR negative & \\
\hline Ehrlichia muris-like & PCR negative & \\
\hline Borrelia burgdorferi & Ab screen negative & Ab screen negative \\
\hline Babesia microti & $\lg G<1: 64$, PCR negative & \\
\hline Babesia duncani & PCR negative & \\
\hline Babesia divergens strain $\mathrm{MO}-1$ & PCR negative & \\
\hline West Nile virus & $\operatorname{lgM} / \lg G$ and $P C R$ negative & IgM/lgG negative \\
\hline Eastern equine encephalitis virus & $\lg M / \lg G<1: 10$ & $\mathrm{lgM} / \lg \mathrm{C}<1: 10$ \\
\hline Western equine encephalitis virus & $\operatorname{lgM} / \lg G<1: 10$ & $\operatorname{lgM} / \lg G<1: 10$ \\
\hline St. Louis encephalitis virus & $\operatorname{lgM} / \lg G<1: 10$ & $\operatorname{lgM} / \lg G<1: 10$ \\
\hline California serogroup virus & $\lg M \geq 1: 10, \dagger \lg G 1: 10$ & $\lg M 1: 80, \lg G 1: 320$ \\
\hline Powassan/tick-borne encephalitis virus $\ddagger$ & IgM negative & \\
\hline La Crosse virus $\ddagger$ & IgM negative, PRNT $<10$ & PRNT 320 \\
\hline Jamestown Canyon virus $\ddagger$ & IgM negative, PRNT 160 & PRNT 10,240 \\
\hline
\end{tabular}

nonspecific mild febrile illness, or severe neuroinvasive disease $(4,7,10)$. This case illustrates a suspected JCV infection causing undifferentiated severe sepsis, which has not, to our knowledge, been previously reported. Initial suspicion for acute neuroinvasive disease was low, and neurologic imaging and cerebrospinal fluid sampling were not performed. We recommend that testing for CAL (and specifically for $\mathrm{JCV}$ ) infection should be strongly considered in the setting of severe sepsis in adults with substantial exposure to mosquitoes and no other identifiable source of sepsis.

\section{References}

1. Deibel R, Grimstad PR, Mahdy MS, Artsob H, Calisher CH. Jamestown Canyon virus: the etiologic agent of an emerging human disease? In: Calisher $\mathrm{CH}$, Thompson WH, editors. California serogroup viruses. New York: Alan R Liss, 1983:313-25.

2. Huang C, Campbell W, Grady L, Kirouac I, LaForce FM. Diagnosis of Jamestown Canyon encephalitis by polymerase chain reaction. Clin Infect Dis. 1999;28:1294-7. http://dx.doi.org/ $10.1086 / 514789$

3. McJunkin JE, de los Reyes EC, Irazuzta JE, Caceres MJ, Khan RR, Minnich LL, et al. La Crosse encephalitis in children. N Engl J Med. 2001;344:801-7. http://dx.doi.org/10.1056/ NEJM200103153441103

4. Grimstad PR. Jamestown Canyon virus. In: Service MW, editor. Encyclopedia of arthropod-transmitted infections of man and domestic animals. New York: CABI Publishing; 2001. p. 235-9.
5. Goff G, Whitney H, Drebot MA. Roles of host species, geographic separation, and isolation in the seroprevalence of Jamestown Canyon and Snowshoe Hare viruses in Newfoundland. Appl Environ Microbiol. 2012;78:6734-40. http://dx.doi.org/10.1128/ AEM.01351-12

6. Andreadis TG, Anderson JF, Armstrong PM, Main AJ. Isolations of Jamestown Canyon virus (Bunyaviridae: Orthobunyavirus) from field-collected mosquitoes (Diptera: Culcidae) in Connecticut, USA: a ten-year analysis, 1997-2006. Vector Borne Zoonotic Dis. 2008;8:175-88. http://dx.doi.org/10.1089/vbz.2007.0169

7. Lindsey NP, Lehman JA, Staples JE, Fischer M. West Nile virus and other arboviral diseases - United States, 2013. MMWR Morb Mortal Wkly Rep. 2014;63:521-6.

8. Neitzel DF, Grimstad PR. Serological evidence of California group and Cache Valley virus infection in Minnesota white-tailed deer. J Wildl Dis. 1991;27:230-7. http://dx.doi.org/10.7589/ 0090-3558-27.2.230

9. Blackmore CG, Grimstad PR. Cache Valley and Potosi viruses (Bunyaviridae) in white-tailed deer (Odocoileus virginianus): experimental infections and antibody prevalence in natural populations. Am J Trop Med Hyg. 1998;59:704-9.

10. Centers for Disease Control and Prevention. Human Jamestown Canyon virus infection-Montana, 2009. MMWR Morb Mortal Wkly Rep. 2011;60:652-5.

Address for correspondence: Daniel K. Rogstad, Division of Infectious Diseases, Department of Medicine, Loma Linda University, 11234 Anderson St, Rm 1521, Loma Linda, CA, 92354, USA; email: drogstad@1lu.edu

\section{Correction: Vol. 21, No. 7}

An additional case report publication was found after publication of Disseminated Infections with Talaromyces marneffei in Non-AIDS Patients Given Monoclonal Antibodies against CD20 and Kinase Inhibitors (J.F.W. Chan al.). An addendum and reference have been added to the article online (http://wwwnc.cdc.gov/eid/article/21/7/15-0138_article). 